\title{
TRIANON PÁRHUZAMOS EMLÉKEZETEI - A TÖRTÉNELMI MAGYARORSZÁG FELBOMLÁSA A RENDSZERVÁLTÁS UTÁNI SZLOVÁK ÉS ROMÁN TÖRTÉNETÍRÁSBAN
}

\author{
PARALLEL MEMORIES OF TRIANON - \\ THE BREAKDOWN OF HISTORICAL HUNGARY IN SLOVAK \\ AND ROMANIAN HISTORIOGRAPHY AFTER 1989
}

\author{
Zahorán Csaba \\ PhD, tudományos munkatárs, BTK Történettudományi Intézet - \\ MTA-Lendület Trianon 100 Kutatócsoport, Nemzeti Közszolgálati Egyetem Eötvös József Kutatóközpont Közép-Európa Kutatóintézet \\ zahorancsaba@gmail.com
}

\section{ÖSSZEFOGLALÁS}

\begin{abstract}
Az első világháború végének emlékezete még napjainkban is megosztja a Magyarországon és a szomszédos államokban élő embereket. Ennek az az elsődleges oka, hogy ez az összetett téma nem válhatott teljesen történelemmé, ugyanis nem csupán a soknemzetiségű történelmi Magyarország felbomlását szentesítő trianoni békeszerződést jelenti, hanem magában foglalja a jelentős, Magyarországon kívüli magyar kisebbségi közösségek létrejöttét és jelenlegi helyzetét is. Az egész kérdéskör tehát nemcsak a történetírással függ össze, hanem a politikával és a hétköznapi élettel is, így nem csoda, hogy még mindig megoldatlan, vagy legalábbis bonyolultnak számít. Mindenesetre, ha csak a témával foglalkozó tudományos közeget nézzük, itt is jól látható törésvonalakat találhatunk a magyar és a szomszédos kutatók értelmezései között. A különbségek alapvetően a múlt nemzeti megközelítésében gyökereznek, és még három évtizednyi korlátlan kutatási szabadság sem volt elegendő ahhoz, hogy jelentősebb mértékben csökkenjenek. Mivel a Trianonnal foglalkozó magyar történetírás viszonylag bőséges, jelen írásban a Trianonnal kapcsolatos szlovák és román történetírásra koncentrálok. Az elhúzódó véleménykülönbségek okait az 1989 utáni főbb irányzatok és a kérdéshez való viszonyulások áttekintésével próbálom megtalálni.
\end{abstract}

\section{ABSTRACT}

The memory of the end of the WW1 is an issue dividing even nowadays the people living in Hungary and the neighbouring countries. It is mainly because this complex topic could not wholly turn into history: it doesn't comprise only the Treaty of Trianon, which confirmed the dissolution of the multi-ethnic historical Hungary but the formation of large Hungarian minority communities outside of Hungary and their current situation. Thus the whole issue is related not only to historiography but also to politics and everyday life, so no wonder, that it is still unresolved or at least complicated. Nevertheless, if we take a look at the academic communities tackling this 
issue, here we can also find visible cleavages between the interpretations of Hungarian and neighbouring researchers. The differences are rooted primarily in the national approaches to the past, and even three decades of unrestricted academic freedom were not enough to reduce them. Since the Hungarian historiography on Trianon is quite rich, in this paper I focus on the Slovak and Romanian historiography related to it. I try to find the causes of tenacious disagreement by reviewing the main currents and attitudes toward this topic after 1989.

Kulcsszavak: emlékezet, történetírás, trianoni békeszerződés, párbeszéd, kisebbségi kérdés, Magyarország, Szlovákia, Románia

Keywords: memory, historiography, Treaty of Trianon, dialogue, minority issue, Hungary, Slovakia, Romania

Az első világháborús évfordulós megemlékezések elmúltával és a trianoni békeszerződés aláírása századik évfordulójának közeledtével újra nyilvánvalóvá vált az az alapvető különbség, amely a magyar és a szomszédos nemzetek történeti tudata között figyelhető meg a világháború következményeinek értelmezése és értékelése tekintetében. Ez nem éppen biztató jelenség, hiszen arról árulkodik, hogy még mindig nem sikerült kimozdulni az egy évszázaddal ezelőtt rögzült ellentétes álláspontokról. Trianon (jelen szövegben 'Trianon' fogalma alatt a történelmi Magyarország 1918-1920 közötti felbomlását és a magyar kisebbségek létrejöttének problematikáját értem) helye és szerepe a régió nemzeteinek történeti tudatában továbbra is megosztó, és bár a párbeszédnek és a vitáknak ma már jóval kevesebb akadálya van, mint a rendszerváltás előtt, csak ritkán van példa teljes egyetértésre.

A magyar történetírás Trianon-diskurzusának örvendetesen gyarapodik a szakirodalma (Romsics, 2015; Ablonczy, 2010; Kovács, 2015; Laczó, 2011; Szidiropulosz, 2002; Zahorán, 2013), ám arról már kevesebbet lehet olvasni - legalábbis magyarul -, hogy miképp értékelik az 1918-1920 közötti eseményeket a szomszédos országokban (Vörös, 2011a; Horbulák, 2010; Kollai-Zahorán, 2007). Pedig ennek ismerete elengedhetetlen ahhoz, hogy megértsük, miért beszélünk még ma is ennyire másképpen ugyanarról az eseménysorról és következményeiről. Az alábbiakban ezért a rendszerváltás óta eltelt időszak szlovák és román eredményeit áttekintve próbálom meg felvázolni ennek az évszázados nézetkülönbségnek a historiográfiai hátterét.

\section{ELŐZMÉNYEK: TRIANON ÉS A RENDSZERVÁLTÁS}

A Csehszlovák Szocialista Köztársaságban és a Román Szocialista Köztársaságban egészen 1989-ig mind a politikában, mind a történettudományban, mind pedig a hétköznapokban látszólag teljes nyugalom övezte Trianon és következ- 
ményei kérdését (amelyek közül kétségkívül a magyar kisebbségek helyzete számít a legfontosabbnak). Ezt a nyugalmat kívülről a térségbeli szovjet hatalmi és ideológiai hegemónia tartotta fenn, amelynek védelmében Trianonról egyáltalán, a kisebbségekről pedig csak szigorúan meghatározott keretek között eshetett szó. Csehszlovákiában és Romániában ezzel kapcsolatban egyfajta konszenzus uralkodott, amelynek alapját néhány axiomatikus tézis képezte, természetesen a megfelelö - marxista - ideológiai csomagolásban. Az egyik az volt, hogy a kisebbségi kérdés teljes mértékben „,belügynek” számít, amelyet a második világháborút követően a szocialista fejlődés oldott meg, sikeresen integrálva a magyar, szlovák, román stb. dolgozókat az egységes társadalmakba. A másik szerint a történelmi Magyarország korszaka már 1918 végén lezárult, amit a második világháború utáni rendezés újra - mégpedig végérvényesen - megerősített, a határkérdés így fel sem merülhet. Végül pedig az, hogy az Osztrák-Magyar Monarchia felbomlásának folyamatából nem is maga a trianoni békeszerződés a lényeges, hanem a szlovákok, románok, magyarok, illetve a többi nemzet önrendelkezése, vagyis kiszabadulásuk a „népek börtöneként” és reakciós képződményként megjelenített birodalomból. E téziseket a magyarországi vezetés sem kérdőjelezte meg nyilvánosan, romániai és csehszlovákiai érvényesülésüket pedig mondhatni hatóságilag is felügyelte a két ország politikai vezetése.

A Közép- és Kelet-Európában az 1980-as évek végén bekövetkező változások azonban megtörték ezt a kényelmes status quót, újra a felszínre hozva számos történelmi kérdést és kényelmetlen ügyet - köztük Trianont és a magyar kisebbségek témáját. Ám míg erre a Magyar Népköztársaságban már a Kádár-rendszer lazulásával párhuzamosan sor került (a történettudományban pedig még korábban, a hatvanas évek közepén elkezdődött) (Romsics, 2015, 353-357.), addig Csehszlovákiában és Romániában egészen 1989 végéig változatlan maradt a helyzet.

A következőkben - a teljesség igénye nélkül - megpróbálom elöször áttekinteni, majd egymással összevetni a szlovák és román történettudomány Trianonnal kapcsolatos főbb megközelítéseit, beazonosítva az egyes nemzeti fősodrok narratíváit és az alternatív viszonyulásokat.

\section{SZOMSZÉDAINK TRIANONJA}

Trianon vonatkozásában a magyar és a szomszédos történetírásokat élesen megkülönbözteti egymástól az a tény, hogy a szlovák és a román szakmai diskurzusokban maga a trianoni békeszerződés csak kevésbé fontos témaként jelenik meg. Ennek ellenére a „tágabb értelemben vett Trianon” - vagyis az Osztrák-Magyar Monarchia felbomlása és az új rend kialakulása, valamint a magyar kisebbségek kérdése - nagyon is jelen van mindkét szomszédos ország 
történeti tudatában, igaz, más formában, mint a magyarban (Šutaj, 2011, 71-74.; Pop, 2020; Kollai-Zahorán, 2007, 35-44.). A 20. század első felével foglalkozó szlovák és román szerzők az időszakkal kapcsolatban elsősorban saját nemzeti közösségük önrendelkezésére koncentrálnak. Vagyis központi témájuk Csehszlovákia, illetve Nagy-Románia létrejötte, az előzmények közül a dualizmus évtizedeinek szlovák és román nemzeti mozgalma, a következmények kapcsán pedig az egyes országok társadalmainak müködése, integrációja. Mindez általában szlovák és román nemzeti nézőpontból történik, a magyar szempontokat többnyire mellőzve vagy csak elnagyoltan megjelenítve. Így míg a dualista magyar államot és felbomlását kisebbségi (nemzetiségi) prizmán át mutatják be, az első világháború után nézőpontot váltanak, és azt követően a többségi (állami) látószög érvényesül.

Miközben a magyar történettudomány fősodrát a 2000-es évekre kikristályosodott „kritikai” - az etnocentrizmussal szakító és objektivitásra törekvő, valamint a tágabb összefüggéseket is szem előtt tartó - szemlélet határozza meg, amelyhez képest a gyakran sérelmi diskurzust alkalmazó „nemzeti” megközelítés periferikusnak számít (Zahorán, 2011, 595-598.), Szlovákiában a korszakot kutató, szakmai szempontból meghatározónak számító fősodor valamivel heterogénebbnek tekinthető. Itt a domináns irányzatba egyaránt beletartozik a két neves, hangsúlyosan nemzeti szemléletü történész - Ladislav Deák (†2011) és Marián Hronský (†2012) -, valamint a többnyire „kritikai” megközelítést alkalmazó, de érveik között nemritkán nemzeti szempontokat is erőteljesen érvényesítő szakemberek, például Dušan Kováč, Bohumila Ferenčuhová, Natália Krajčovičová, Milan Zemko (†2013), Roman Holec és Štefan Šutaj. A magyar történetírás - érthető okokból - bőséges szakirodalmához képest Szlovákiában csak kevesen, elsősorban Deák és Hronský számára jelentett központi témát Trianon, az ő hatásuk jelenleg is érezhető a kérdés szlovák értelmezésében. Rajtuk kívül még Miroslav Michela és Vörös László foglalkoztak vele behatóbban (Vörös, 2011a), a többiek viszont inkább a (cseh)szlovák államalakulás kontextusában érintik a kérdést (Holec, 2011, 109-132.; Šutaj, 2011, 71-85.; Horbulák, 2010, 23-35.). Itt érdemes megjegyezni, hogy bár szlovák kontextusban is javában folyik a történeti mítoszok lebontása (Krekovič et al., 2005), illetve az új elméleti megközelítések alkalmazása, még tartja magát jó néhány, a magyar-szlovák múltra vonatkozó régi toposz (Simon, 2005), ami Trianon kérdéskörének értelmezését is befolyásolja.

A korszakot taglaló munkákból mindenesetre a magyar történetírásétól jelentősen eltérő kép rajzolódik ki. A szlovák szövegekben alapvetően egy, a háborús vereség és az államtól elidegenített nemzetiségek - illetve elitjeik - tevékenysége következtében dezintegrálódó Magyarország jelenik meg, amelynek a története 1918-ban véget ért. A korábban elnyomott és erőteljes magyarosításnak kitett szlovákok ekkor érvényesíthették nemzeti önrendelkezésüket, amit addig 
a soknemzetiségủ Magyarországot magyar nemzetállammá átalakítani kívánó magyar elitek megtagadtak tőlük. A kisszámú, de aktív szlovák nemzeti elit szervezésében (turócszentmártoni nyilatkozat), a csehek katonai és diplomáciai segítségével és az antanthatalmak hathatós támogatásával lezajlott folyamatot végül a trianoni békeszerződés hagyta jóvá nemzetközi szinten. Fontos eleme ennek a narratívának, hogy a magyar nemzet államaként létrejött Magyarország ugyanolyan utódállama lett a Monarchiának, mint a többi (Juhász, 2007, 31.). A diszkontinuitás kihangsúlyozásához a szlovák terminológia is hatékony segítséget nyújt: az Uhorsko és Mad’arsko kifejezések következetes használata ugyanis éles határt húz a történelmi - multietnikus - és a „trianoni” - etnikai - Magyarország között. Vagyis „Mad’arsko” tulajdonképpen nem is veszített el területeket, hiszen csak akkor született a felbomló „Uhorsko” központi részeiből (Šutaj, 2014, 472-475.). Az új rendezés értékelésekor gyakran kerülnek elő az „előzmények”, vagyis a dualizmus korszaka, különösen a magyar elitek mulasztásai és hibái (Ficeri, 2019, 772-776.). A 19-20. századi magyar nemzetállam-építést sokszor az első köztársaság demokratikusabb viszonyainak tükrében értelmezik a szlovák történészek (Horbulák, 2010, 27.; Holec, 2011, 119-120.). A Károlyi-kormányzatnak a területi integritás megőrzésére irányuló, nemzeti autonómiát felajánló javaslatai és erélytelen ellenállása, majd a Magyarországi Tanácsköztársaság védekezése és ellentámadása, végül az ellenforradalmi rezsim revizionizmusa pedig gyakran esik hasonló elbírálás alá: azaz egyformán a magyar szupremácia megőrzésére tett agresszív, de hiábavaló kísérletekként jelennek meg (Horbulák, 2010, 30.).

Ami a magyar-(cseh)szlovák határ kijelölését illeti, a szlovák szerzők alapvetően a nemzeti elv alkalmazását említik. Miközben gyakran hangsúlyozzák, hogy a korábbi népességmozgás és a keveredés következtében nem lehetett megállapítani a tiszta etnikai határt, utalnak Csehszlovákia és a szlovákok gazdasági, közlekedési és földrajzi érdekeire is (Deák, 2004, 21-23.; Kollai-Zahorán, 2007, 40.). A rendezés igazságossága vagy igazságtalansága kapcsán pedig általában a morális nézőpont értelmetlensége (Juhász, 2007, 31-32.), illetve a háborús felelősség kérdése vetődik fel a szlovák történetírásban (Holec, 2011, 119.; Ficeri, 2019, 763-776.).

Egyértelmủen a kritikai irányzathoz tartoznak, de új témáik és megközelítéseik révén a fösodorhoz képest kétségkívül alternatívát kínálnak például Elena Mannová, Miroslav Michela, valamint Vörös László munkái. Ők kevésbé foglalkoznak az eseménytörténettel - igaz, azt sem hagyják figyelmen kívül -, helyette inkább az identitásra (Mannová, 2000, 93-103.), a historiográfiára és emlékezetre (Vörös, 2011a, 5-43.; Kusá-Michela, 2011, 53-69.) és különféle elméleti kérdésekre (Vörös, 2011b) koncentrálnak. Bár a Miroslav Michela és Vörös László által Trianon magyar és szlovák emlékezetéről összeállított kiváló kötet (MichelaVörös, 2013; Limes, 2010-2011) módszertani szempontból és a magyar-szlovák 
párbeszéd vonatkozásában egyszerre tekinthető úttörő munkának a közös múlt feltárásában, kérdésfelvetéseikkel (még?) nem tudták jelentősebb mértékben módosítani a szlovák fősodor narratíváját.

A korszakot vizsgáló román történetírás fősodrának jellege a szlovákhoz hasonlóan vegyes, azzal a különbséggel, hogy itt még határozottabban érezhető a nemzeti megközelítés túlsúlya a kritikai irányzattal szemben. Ez részben az 1989 előtti személyi folytonosságból is következik, és számos, korábbi időszakokból származó történeti klisé továbbélésében nyilvánul meg. A románok 20. századi történetét kutató - így Trianon kérdését is érintő - elismert szakemberek közé tartozik például Ioan Scurtu, Ion Agrigoroaiei, Constantin Botoran, Liviu Maior, Gheorghe Iancu, Adrian Ivan, Lucian Leuștean, továbbá olyan hadtörténészek, mint Dumitru Preda, Vasile Alexandrescu vagy Costică Prodan, újabban pedig a „Nagy Egyesülés” centenáriuma kapcsán gyakran megszólaló Ioan-Aurel Pop. Mint ahogy a szlovák történészek, a románok is alapjában véve saját nemzeti narratívájuk logikája mentén, azaz a román nemzeti egység megvalósulása felől közelítenek Trianonhoz, amely így inkább csak közvetve jelenik meg munkáikban (Pataky, 2019, 6.).

A román történetírás hagyományosan nagy figyelmet szentelt a román lakosságú területek első világháború végén történő egyesítésének. A „Nagy Egyesülés" irodalma már a két világháború közötti időszakban gyarapodásnak indult, ami - az ötvenes évek internacionalista szakaszát követően - a nemzeti kommunizmus alatt, majd 1989 után megújult formában, de lényegét tekintve változatlanul folytatódott (Scurtu, 2010, 20-40.; Petrescu, C.-Petrescu, D., 2007, 311-408.). A magyar és a szlovák narratívához képest az egyik legfontosabb sajátossága abból az általánosan elfogadottnak számító tézisből következik, amely szerint a román történelem kiindulópontja a dák-római-román szintézis és kontinuitás, és végeredményben abból eredezteti a románok etnikai-történeti jogát az 1918-1919 folyamán egyesített területekre is. Ennek megfelelöen Nagy-Románia megalakulása tulajdonképpen a „román nemzeti tér” - a hagyományosan „román országoknak” nevezett Havasalföld, Moldva és Erdély újraegyesítését jelentette. Vagyis annak a régóta áhított nemzeti egységnek a létrejöttét, amit egykor a magyar honfoglalás és államszervezés, illetve a többi idegen hódító akadályozott meg, azaz egy természetes és törvényszerü történeti folyamat lezárásáról van szó. Jól kifejezi ezt a viszonyulást az egyik neves román történész megállapítása, aki szerint Nagy-Románia valójában nem „nagy” volt, hanem „természetes, olyan ország, amely megegyezik természetes határaival" (Constantiniu, 2002, 283.).

A román fösodron belül általánosnak tekinthető konszenzus övezi azt az állítást, hogy a románok elsősorban saját erejükből teremtették meg Nagy-Romániát, vagyis hogy az nem a „nagyhatalmak ajándéka” volt. A párizsi békekonferencia így csupán szentesítette a hatalmas háborús áldozatok árán és a nemzeti önren- 
delkezés érvényesítésével elért román eredményeket (Scurtu, 2010, 50.). Ennek megfelelően Erdély csatlakozása a Román Királysághoz az erdélyi román elitek hosszan tartó aktivitásának és az 1918. őszi nemzeti mozgósításnak a következménye volt, és a bevonuló román hadsereg és az antant támogatásával kerülhetett rá sor. A román nemzeti egység létrejötte megfelelt a kor demokratikus gyakorlatának (Pop, 2017, 182-187.), a wilsoni elvek alkalmazását pedig nemcsak a Romániához csatlakozó területek lakosságának román többsége igazolta, hanem az azt kimondó népgyülések - ,,a román nemzet spontán népszavazásai” (Botoran-Dobrinescu, 2003, 5-6.) - is legitimálták. A fősodorhoz tartozó román történészek hangsúlyozzák a széles társadalmi bázisra épülő román egységtörekvés demokratizmusát, szembeállítva az akkor Magyarországon terjedő szélsőséges - bolsevik - megnyilvánulásokkal (Agrigoroaiei, 2003, 510-524.). Itt a román történeti tudat egyik elterjedt toposza is hasznosul, amely szerint az 1919-es, Budapest megszállásával végződő román hadjárat a magyarokat és Közép-Európát egyaránt segített megmenteni a bolsevizmustól.

Ennek ellenére a későbbi történetírás, majd különösen a 2018-as századik évforduló környékén megszaporodó történeti és emlékezetpolitikai irodalom nagyobb részét egyfajta triumfalista megközelítés jellemzi Nagy-Románia létrejötte vonatkozásában. Alapját egyrészt az első világháború Románia szempontjából csodával határos befejezése képezi, másrészt az a morális elégtétel, amely a történelmi szerepcseréből következik - azaz hogy az alávetettség évszázadai után végre a többségi románok dominanciája érvényesülhetett Erdélyben is (Pop, 2017, 187-188.) -, végül pedig az a tény, hogy mind a második világháborút, mind a hidegháború lezárását Románia némi veszteséggel, de sikerrel vészelte át, és nem jutott az 1918-ban létrejött államszövetségek sorsára. Ahogy Lucian Leuștean fogalmazott: a „trianoni békét végül is »jóváhagyták« a nagyhatalmak, Európa, a civilizált világ, mindazok, akik számítanak - vagyis a Történelem" (Leuștean, 2005, 259.). Ezt kiegészíti még a magyarok fölött aratott győzelem és Budapest román megszállásának emlékezete (Historia special, 2019). Az új határok kijelölése kapcsán a román munkákban általában az etnikai elv érvényesülése szerepel, amit a Romániával egyesült tartományok román többsége támaszt alá, az ezzel csak nehezen összhangba hozható részletekre pedig többnyire nem térnek ki a szerzők. Összességében véve ezt tükrözi Románia december elsejei nemzeti ünnepe is, amely Erdély csatlakozásának évfordulóján keresztül hivatott minden évben felidézni a román nemzeti egység és önrendelkezés diadalát.

Mindennek tükrében Trianon kapcsán nem sok empátiát várhatnak a magyarok - annál is inkább, hogy bármilyen, ezen a területen nyújtott „engedmény” a román nacionalisták szemében csak a folyamatos, jelenleg is zajló román nemzetállam-építés legitimációját gyengítené (Pop, 2017, 193-194.). A „román igazság győzelmét" kellene hirdetniük azoknak az időnként a bukaresti tör- 
vényhozás elé kerülő - politikailag motivált - kezdeményezéseknek is, amelyek emléknapként kodifikálnák a trianoni békeszerződés aláírásának évfordulóját (Propunere, 2019).

Ami a román fösodortól való eltérést illeti, például Lucian Leuștean ugyan alapjaiban nem kérdőjelezi meg a nemzeti narratívát, de - elsősorban diplomáciatörténeti témájú munkájában - több ponton is megpróbálja kiigazítani a nemzeti motivációjú torzításokat (Leuștean, 2002, 77-86., 140-151.). A kritikai irányzathoz tartozó történészek viszont elsősorban az eszme- és társadalomtörténet, illetve az emlékezet területén szállnak vitába a fentebb említett szerzőkkel. Egyik legismertebb képviselöjük a Romániában és külföldön egyaránt elismert és népszerü Lucian Boia, aki a román történeti mítoszok dekonstruálását követően újabb könyveiben és történeti esszéiben az első világháború hagyományos román narratíváját is kritikai vizsgálat alá vette (Boia, 2015, 2018). Továbbá ide köthető még több, föleg külföldön ténykedő román történész is, mint például Irina Livezeanu (2000), Constantin Iordachi (2018), Răzvan Pârâianu (2018) és Maria Bucur (2009).

\section{SZLOVÁK-ROMÁN PÁRHUZAMOK}

Ha a magyar történettudomány Trianon-diskurzusához mérjük, a szlovák és a román valamivel statikusabbnak tünik, azaz a belső viták kevésbé látványosak, és mindkét szomszédos országban nemzeti szempontból meghatározottabbnak tủnik a korszak fösodratú narratívája.

Mindkét esetben sokszor érezhető egyfajta retrospektivitás, vagyis hogy az 1918-1920 közötti események a mai Szlovákia vagy Románia felől visszatekintve kerülnek bemutatásra. Ez eklatáns módon nyilvánul meg az igényelt magyarországi területek elfoglalásának ábrázolásakor, amikor a nemritkán még napjainkban is magyar többségü településeket „felszabadították” a csehszlovák és román csapatok, vagy amikor a - tulajdonképpen a Magyarország területét védelmező - magyar hadsereg „támadásait” kellett „visszavernie” a csehszlovák és román erőknek.

Közös vonás a népakarat hangsúlyozása a történelmi Magyar Királyság felbomlása kapcsán, kiemelve az önrendelkezés alulról jövő, demokratikus jellegét. Hasonlóan fontos, hogy a Monarchia - és azon belül Magyarország - szétesését gyakorlatilag törvényszerüként kezelik: egy megreformálhatatlan és a háború végére müködésképtelenné vált birodalom összeomlásaként, ami után a multietnikus Monarchia helyébe modern nemzetállamok léptek. Ezt a folyamatot a Párizs környéki békerendszer szentesítette véglegesen, amely nemcsak az európai béke és a regionális stabilitás garanciája lett, hanem - az akkor meghúzott határokkal együtt - az „idők próbáját” is kiállta. Érdekes módon ezt az álláspontot a ver- 
sailles-i békemü 1938-1940 közötti szétesésének - vagy az 1989 utáni átalakulásoknak - a ténye sem bizonytalanítja el.

A már említett retrospektivitással is összefügg, de föként a Trianonhoz mint lezárt - és kizárólag történelmi - kérdéshez való viszonyulást szemlélteti az is, hogy a mai magyar kisebbségek kérdését szinte teljesen leválasztják a száz évvel ezelőtti folyamatokról. Az 1918-1920 utáni status quo „természetessége” miatt Trianonhoz általában csak a kisebbségbe került magyarok „beilleszkedési problémáit" kötik, vagyis hogy sokáig nem tudtak megbékélni korábbi domináns pozíciójuk elvesztésével. A kisebbségek kapcsán időnként egy súlyos torzítás is előfordul, mégpedig mind szlovák, mind román részről. Azonkívül, hogy rendszerint kétségbe vonják a magyar statisztikák - különösen az 1910-es népszámlálás eredményeinek - valóságalapját (miközben „saját” népszámlálásaikat fenntartások nélkül kezelik), kevesebb elcsatolt magyarral számolnak, illetve - mintegy az új magyar kisebbségek „ellensúlyozásaként” - jelentősen túlbecsülik a Magyarországon maradt szlovákok/románok számát (Kollai-Zahorán, 2007, 40-41.).

Végül pedig a szlovák és a román történetírás fösodrának Trianon-diskurzusát egyformán meghatározza, hogy a történelmi Magyarország felbomlása és a trianoni békeszerződés a saját nemzeti narratívában egyfajta „aranykorként” ábrázolt, két világháború közötti korszak előjátékaként jelenik meg. A régi világot megtestesítö történelmi Magyarországnak el kellett pusztulnia, ténylegesen is történelemmé kellett válnia ahhoz, hogy megszülethessen a dinamikusan fejlődő első Csehszlovák Köztársaság - ahol befejeződhetett a modern szlovák nemzet kialakulása -, valamint a román nemzeti aspirációkat beteljesítő Nagy-Románia. Ez pedig a szlovák és a román történeti tudatban mintegy visszamenőlegesen is legitimálja 1918-at.

\section{KONKLÚZIÓ}

Mindezt figyelembe véve, nem csoda, hogy még a sorsfordító 1918-1920-as események századik évfordulóján sem könnyü Trianonról szót érteniük egymással a magyar és a környező nemzetek történészeinek (Romsics-Zahorán, 2019, 777788.). Különösen a történelmi sérelmek és a jelenlegi kisebbségi kérdés összefonódása nehezíti meg a párbeszédet. Magyar szemmel ugyanis gyakran tünik úgy, mintha a szlovák és a román történetírásra még mindig túlságosan nagy súlylyal nehezedne az a legitimációs kényszer, amely a Párizs környéki rendezésben a jelenlegi status quo igazságos és megkérdôjelezhetetlen alapját látja, és ezért elutasítja - vagy kerülni igyekszik - annak kritikai vizsgálatát. Bár a politikai rendszerváltások után a demokratikus viszonyok régen látott esélyt biztosítottak a szakmai eszmecserékre és a vitás kérdések szabad ki- és megbeszélésére, amit az újabb történész- és társadalomtudós nemzedékek felkészültsége és lehetőségei 
is növelnek, a kusza és viszonylag gyorsan változó politikai közeg - az államközi kapcsolatoktól az egyes országok belpolitikai színteréig - nem mindig kedvez a történeti és emlékezetpolitikai nézeteltérések tisztázásának. Jó néhány, a korábbi korszakokból megörökölt reflex, elöítélet és sztereotípia, illetve a szakmai mühelyek nehézségei - pénzügyi, kapacitás- vagy infrastrukturális hiányosságok sem kifejezetten ösztönzik ezt a párbeszédet.

\section{IRODALOM}

Ablonczy B. (2010): Trianon-legendák. Budapest: Jaffa Kiadó

Agrigoroaiei, I. (2003): Marea Unire. In: Platon G. (ed.) (2003): Istoria Românilor VII/II. De la independență la Marea Unire (1878-1918). București: Editura Enciclopedică, 463-532.

Boia, L. (2015): Vesztesek és győztesek. Az első világháború újraértelmezése. Budapest: Cser Kiadó

Boia, L. (2018): Az 1918-as nagy egyesülés. Nemzetek, határok, kisebbségek. Kolozsvár: Koinónia Kiadó

Botoran, C. - Dobrinescu, V. F. (2003): Confirmarea internațională a actelor de Unire din 1918. In: Scurtu, I. (ed.) (2003): Istoria Românilor VIII. România Întregită (1918-1940). București: Editura Enciclopedică, 3-30.

Bucur, M. (2009): Heroes and Victims: Remembering War in Twentieth-Century Romania. Bloomington, IN: Indiana University Press, https://www.researchgate.net/publication/290603911_ Heroes_and_victims_Remembering_war_in_twentieth-century_Romania

Constantiniu, F. (2002): O istorie sinceră a poporului român. București: Univers Enciclopedic, https://www.academia.edu/25081561/O_ISTORIE_SINCERA_A_POPORULUI_ROM\% $\mathrm{C} 3 \% 82 \mathrm{~N}$

Deák L. (2004): Miesto Slovenska v československom štáte v rokoch 1918-1938 z medzinárodného hladiska. In: Zemko, M. - Bystrický, V. (eds.): Slovensko v Československu (1918-1939). Bratislava: VEDA, 15-34.

Ficeri, O. (2019): Vállalni a felelősséget Trianonért. (ford. Zahorán Cs.) Történelmi Szemle, LXI, 4, 763-776. https://www.researchgate.net/publication/339484904_Vallalni_a_felelosseget_Trianonert_A_Tortenelmi_Szemle_2019_LXI_4

Historia special (2019): 100 ani de la intrarea armatei române în Budapesta. VIII, 27.

Holec, R. (2011): Trianoni rituálék, avagy gondolatok a magyar historiográfia egyes jelenségeiről. (ford. Zahorán Cs.) Fórum, 4, 109-132. http://forumszemle.eu/archiv/?szemle=2011-4

Horbulák Zs. (2010): Trianon-kép a szlovák történettudományban. Magyar Napló, 22, 8, 23-35. http://epa.oszk.hu/03500/03573/00052/pdf/EPA03573_mn_2010_08_23-35.pdf

Iordachi, C. (2018): Cuvânt-înapoi. In: Bucur, B. (ed.) (2018): Cartea de aur a Centenarului Marii Uniri. Ediția a II-a revăzută și adăugită. București: RAO, 721-742.

Juhász K. (szerk.) (2007): Trianon - Trianon és bon ton. (Visegrádi Füzetek) Pozsony: Palisády-Védcölöp Alapítvány, http://www.visegradgroup.eu/visegrad-parlour/trianon-110412

Kollai I. - Zahorán Cs. (2007): Trianon a román és szlovák köztudatban. Kommentár, 3, 35-44. http://adatbank.transindex.ro/html/cim_pdf2293.pdf

Kovács É. (2015): Trianon, avagy „traumatikus fordulat” a magyar történetírásban. Korall, 59, 82-107. http://real.mtak.hu/31414/1/Korall_59.pdf

Krekovič, E. - Mannová, E. - Krekovičová, E. (eds.) (2005): Mýty naše slovenské. Bratislava: AEP 
Kusá, D. - Michela, M. (2011): A kulturális trauma diskurzusa. Trianon és a szlovák-magyar kapcsolatok reprezentációi. Limes, 1, 53-70.

Laczó F. (2011): The „Trianon” - Debate in the Hungarian Left-liberal Weekly Élet és Irodalom. In: Cultures of History Forum. https://www.cultures-of-history.uni-jena.de/debates/hungary/ the-trianon-debate-in-the-hungarian-left-liberal-weekly-elet-es-irodalom/

Leuștean, L. (2002): România, Ungaria și Tratatul de la Trianon (1918-1920). Iași: Polirom

Leuștean, L. (2005): Trianon - történelem és propaganda. Múltunk, 2, 254-260.

Limes (2010-2011): Magyarország felbomlása és a trianoni békeszerződés a magyar és a szlovák kollektív emlékezetben 1918-1920. I-II. Limes, 1, 4. I: http://www.jamk.hu/ek/folyoirat/ folyoirat/limes/2010_4.pdf

Livezeanu, I. (2000): Cultural Politics in Greater Romania: Regionalism, Nation Building, and Ethnic Struggle, 1918-1930. Ithaca-London: Cornell University Press

Mannová, E. (2000): „... de most már jó szlovák” A nemzeti identitás variációi két dél-szlovákiai kisváros egyesületi életében, 1918-1938. Regio, 4, 93-103. http://epa.oszk.hu/00000/00036/00038/ pdf/05.pdf

Michela, M. - Vörös L. et al. (2013): Rozpad Uhorska a trianonská mierová zmluva. K politikám pamäti na Slovensku a v Mad'arsku. Bratislava: HÚ SAV, https://www.academia.edu/7655941/ Rozpad_Uhorska_a_Trianonsk\%C3\%A1_mierov\%C3\%A1_zmluva._K_politik\%C3\%A1m pam\%C3\%A4ti_na_Slovensku_a_v_Ma\% $\%$ C $4 \% 8$ Farsku

Pataky I. (2019): Trianon nem mond semmit a románoknak. Krónika, 2019. december 9, 6. https:// kronikaonline.ro/belfold/trianon-nem-mond-semmit-a-romanoknak-szakertok-szerint-parbeszed-helyett-a-tortenelemmel-manipulalnak-a-politikusok\#

Pârâianu, R. (2018): An Experiment that Failed: The Liberal Greater Romania. In: Rumpler, H. Harmat U. (Hgg.): Die Habsburgermonarchie 1848-1918, Band XII. Bewältigte Vergangenheit? Wien: VÖAW, 255-281. https://bit.ly/3a3QeFd

Petrescu, C. - Petrescu, D. (2007): Mastering vs. Coming to Terms with the Past: A Critical Analysis of Romanian Post-Communist Historiography. In: Sorin Antohi, S. - Apor P. - Trencsényi B. (eds.): Narratives Unbound: Historical Studies in Post-Communist Eastern Europe. Budapest: Central European University Press, 311-408. https://www.researchgate.net/publication/328234129_Mastering_vs_Coming_to_Terms_with_the_Past_A_Critical_Analysis_of_ Romanian_Post-Communist_Historiography

Pop, I-A. (2017): Semnificaţia anului 1918 pentru istoria românilor - câteva consideraţii. In: Orga, V. - Traşcă, O. - Ţîrău, L. et al. (eds.): Din modernitate spre contemporaneitate. Studii istorice dedicate lui George Cipăianu la împlinirea vârstei de 75 de ani. Cluj-Napoca: Argonaut, $180-195$.

Pop, I-A. (2020): Câteva gânduri legate de Trianon. Jurnalist.ro, https://jurnalist.ro/cateva-ganduri-legate-de-trianon/

Propunere (2019): Propunere legislativă pentru declararea zilei de 4 iunie Ziua Tratatului de la Trianon. https://www.senat.ro/legis/PDF/2019/19L459FS.PDF

Romsics I. (2015): A múlt arcai. Történelem, emlékezet, politika. Budapest: Osiris Kiadó, 331-365.

Romsics G. - Zahorán Cs. (2019): Útkereső történészek. Megjegyzések egy lezáratlan eszmecsere margójára. Történelmi Szemle, 4, 777-788.

Scurtu, I. (2010): Istoria românilor de la Carol I la Nicolae Ceaușescu. București: Editura Mica Valahie

Simon A. (ed.) (2005): Mýty a predsudky v dejinách. Šamorín-Dunajská Streda: Fórum inštitút pre výskum menšín-Lilium Aurum, https://mek.oszk.hu/02900/02925/

Šutaj, Š. (2011): Trianon a szlovákiai történelmi emlékezetben. Limes, 1, 71-86. 
Šutaj, Š. (2014): Niektoré problémy interpretácie slovenských a mad’arských dejín v súčasnosti. In: Szigeti L. (ed.): V službe demokracie. Pamätnica k sedmdesiatke Martina Bútoru. Bratislava: Kaligram, 471-491.

Szidiropulosz A. (2002): Trianon utóélete. Válogatás a magyar nyelvü irodalom bibliográfiájából 1920-2000. Budapest: XX. Század Intézet-Kairosz Kiadó

Vörös L. (2011a): A történelmi Magyarország szétesése és Trianon. Az 1918-1920-as évek megjelenítése a magyar és a szlovák nemzeti történetírásban. Limes, 1, 5-44.

Vörös L. (2011b): Analytická historiografia versus národné dejiny. Pisa: Pisa University Press, http://www.forumhistoriae.sk/sites/default/files/voros-analyticka_historiografia_vs_narodne_dejiny1_0.pdf

Zahorán Cs. (2011): A Trianon-jelenség pozsonyi tükörben. Történelmi Szemle, 4, 591-613.

Zahorán Cs. (2013): A trianoni labirintus. In: Szalai László: A nemzeti mitoszok szerkezete és funkciója Kelet-Európában. Budapest: L'Harmattan Kiadó - ELTE BTK Kelet-Európa Története Tanszék, 9-54. https://edit.elte.hu/xmlui/static/pdfjs/web/viewer.html?file=https://edit. elte.hu/xmlui/bitstream/handle/10831/43402/01_ZahoranCs_9-54.pdf?sequence=1\&amp;isAllowed $=\mathrm{y}$

Zahorán Cs. (2019): „Addig a békesség, míg szomszéd akarja”. Trianon és a magyar-szomszéd viszony napjainkban. Történelmi Szemle, 4, 731-743. 